\title{
SOCIAL INVESTMENTS AT A GLANCE: REVIEWING RUSSIAN PERSPECTIVES
}

\author{
E.S. Votchenko, I.V. Bogdashev \\ Kuban State University \\ Stavropolskaya str., 149, Krasnodar, Russia, 350040
}

\begin{abstract}
The aim of the research is to analyze the modern trends and today's development stage of social investments and corporate social responsibility (CSR) in Russia. The article touches a vital topic of contemporary relations of the triada "state-business-society" in Russian public discourse. Considering the system approaches and development methodology of business and government relations, the authors try to summarize the accumulated experience in CSR and social investments field. It is worth noting that Russian scientists successfully carried out the subject of the research and the conceptual apparatus, defined and systematized public expectations, analyzed and summed up real experience of socially responsible Russian and foreign companies. The article shows an interesting phenomenon that in modern scientific community is forming and becomes stable a new institutional paradigm when CSR in the narrow sense goes beyond charity and philanthropy, and today it is expressed in a broad sense - as corporate citizenship, including some political dimensions. Besides, the article highlights indicative results on the authors' applied research "Experience analysis of social partnerships between business and government, social investments and corporate social responsibility" hold in Krasnodar and Rostov-on-Don, Russia, in 2016-2017.
\end{abstract}

Key words: corporate social responsibility, CSR, social investments, public-private partnerships, business and government relations, corporate citizenship

\section{Introduction}

CSR is a dynamic phenomenon and quite challenging to analyze. In the light of growing emphasis on multidimensional aspects of social partnerships, we consider stages and trends of Russian indicators of CSR development process in addition to the "statebusiness-society" triada. Practical implications of the article are to investigate Russian contribution to the global corporate citizenship and to compare Russian trends in corporate social responsibility with European experience. This is a scope and key objective of our research and the next step to the following one. To the authors' mind, the essence of corporate interactions with any stakeholders called social investments that are forming around the image and reputation of modern business and directly involving social sphere issues. For the Russian business community it provides a unique opportunity to build partnerships with the equilibrium potential clients (customers, public authorities, media, experts, suppliers, compliance control bodies, NGOs, etc.).

In general, economic and institutional aspects of large business development are reflected in the works of Ya. Pappe (2004), A. Dynkin (2004), political aspects of interaction 
between business and government accumulated in studies of S.P. Peregudov $(2003,2006$, 2008), A. Zudin (2001, 2006), A. Pavroz (2010). In regional perspective, this topic considered by N.Ya. Lapina (2002, 2007), A.E. Chirikova (2002), R. Turovskiy (2001). Constructive interaction between business and government, indicative aspects of public policy are analyzed in the complex approach of V.N. Yakimets $(2001,2005)$ and M.B. Gorniy (2013). In this regard, serious attention should be paid to the research of Yu. Blagov $(2004,2011)$, an expert in CSR. In his scientific works the author analyzes the evolution of CSR concept in Russia and sees the connection of this theory with strategic management.

The authors conducted an independent applied research "Experience analysis of social partnerships between business and government, social investments and corporate social responsibility". The research was built on political and sociological basis with the support of qualitative methods. Survey tool: expert questionnaire. Method of collecting primary information: personal interview. Main research technique: semi-standardized interview. Methodological principles of the CSR-concept proposed by A.B. Carroll $(1979,2001)$. The authors interviewed representatives of the business community of the two cities, representatives of public authorities and civil society (45 specialists). Respondents were divided into the following 5 categories: business community; non-profit sector; public authorities; scientific community; PR and marketing agencies whose work is related to interaction with all categories of experts.

\section{Corporate citizenship: is there any in Russia?}

Social aspects of business and government relations in the field of CSR can be interpreted, inter alia, as a phenomenon of corporate citizenship. Wherein short-term costs of the company do not provide immediate financial returns, but instead help promote positive social changes in the future.

Russian experts (Peregudov S.P., Semenenko I.S., 2008) referred to corporate citizenship as to systematic business interactions with government and non-profit sector in a partnership to a mutually beneficial company's development strategy and solutions to global problems. In the Russian Federation there was an interaction evolved in a unique model that had various objectives and laws in different historical periods. It was the evolution of public-private partnerships, business relations with the state and nongovernmental organizations to identify trends and specifics of corporate citizenship and CSR concepts in Russia.

A number of researchers of the interaction processes between business and government (S. Peregudov, J. Pappe, A. Zudin, A. Pavroz) believe that contemporary Russia has experienced five stages of transformation between private and public sectors' relations for the past twenty years - the sixth one is forming nowadays in conditions of global financial crisis and the process overcoming its consequences. It is a way to realize the resource capital transformation of business corporations and it is typical for a new stage. Today political and administrative stakeholders occupy the leading position.

For example, the analyst of inter-corporate and governmental relations S.P. Peregudov reveals and systematizes important subordinate aspects of public authorities and business 
relations with corporations in the EU member states, in the US and Russia. The scientist especially points out the growing demand of the state structures for external expertise of political decision-making and projects developed by the government, as well as "strengthening the influence of large corporations operating in their business interests and the role of "expertocracy" in various echelons of public authority" (Peregudov S.P., 2008). The authors of this article completely share the scientist position stressing that today in a multilevel aspect public authorities need the expert opinion of the professional business community, in the ways of organizing various conferences, round tables, forums both on issues of political agenda and on the problems of socioeconomic sustainable development. Taking into account the influence of such interactions, we can observe a change in the functions and roles of corporations. Business goes to social sphere, becomes a social investor (or social entrepreneur as the European Commission defines) and driver of social changes, investing resources in the field of its philanthropic interests.

We emphasize that today such business associations are becoming an economy-driver for social change and forming a new phenomenon of "expertocracy" providing unique professional information and expert assessments for government officials in various areas: financial and social investments, international standardization, environmental protection and green economy, etc. So, the business on a voluntary basis has the opportunity to open access to expert assessments for public authorities, relevant practical information and analysis that it is impossible to obtain as quickly and reliably as they do from other sources, even with political lobbying. According to some Russian researchers, "expertocracy" promotes greater legitimation and effective implementation of political decisions (Korolev E.A., 2009).

As we can see, business operates under pressure, and corporate citizenship approaches give corporations and the entire business community the opportunity not only responding to the pressure of the authorities and society, but also actively influence to the socioeconomic environment to their own advantage. There has a new paradigm of social responsibility arisen. Its elements are:

1. Corporate citizenship that implies mutual responsibility of business to society and the authorities as well as taking into account entrepreneurs' interests either in economic or in the social sphere. Mutually beneficial business arrangements of social investments in society are the important elements of creating a business strategy and negotiating power.

2. Social investments that are expanding the concept of CSR. Moving from charity to social investments focused on a national and regional level, they aimed at addressing the most urgent questions for the country in the field of employment, poverty alleviation, education, housing, security, health and environment.

3. Social partnerships review areas of mutual responsibility of business, government and society in socially significant issues: eradication of social inequality, establishment of public control mechanisms. There are so called "social lobbying" functions imposed on "corporate citizens" in the context of weak civil society (Turkin S., 2004).

According to the authors' research (Votchenko E.S., 2016, 2018), growth process from an ordinary manager to responsible top-manager encompasses following stages as showed at the Figure "CSR Pyramid in Russia". Unlike the classic "CSR pyramid" proposed by 
A.B. Carroll, the American founder of the corporate social responsibility concept in his articles (Carroll A.B., 1979, 1991), we have almost all active components of the pyramid but in different proportions:

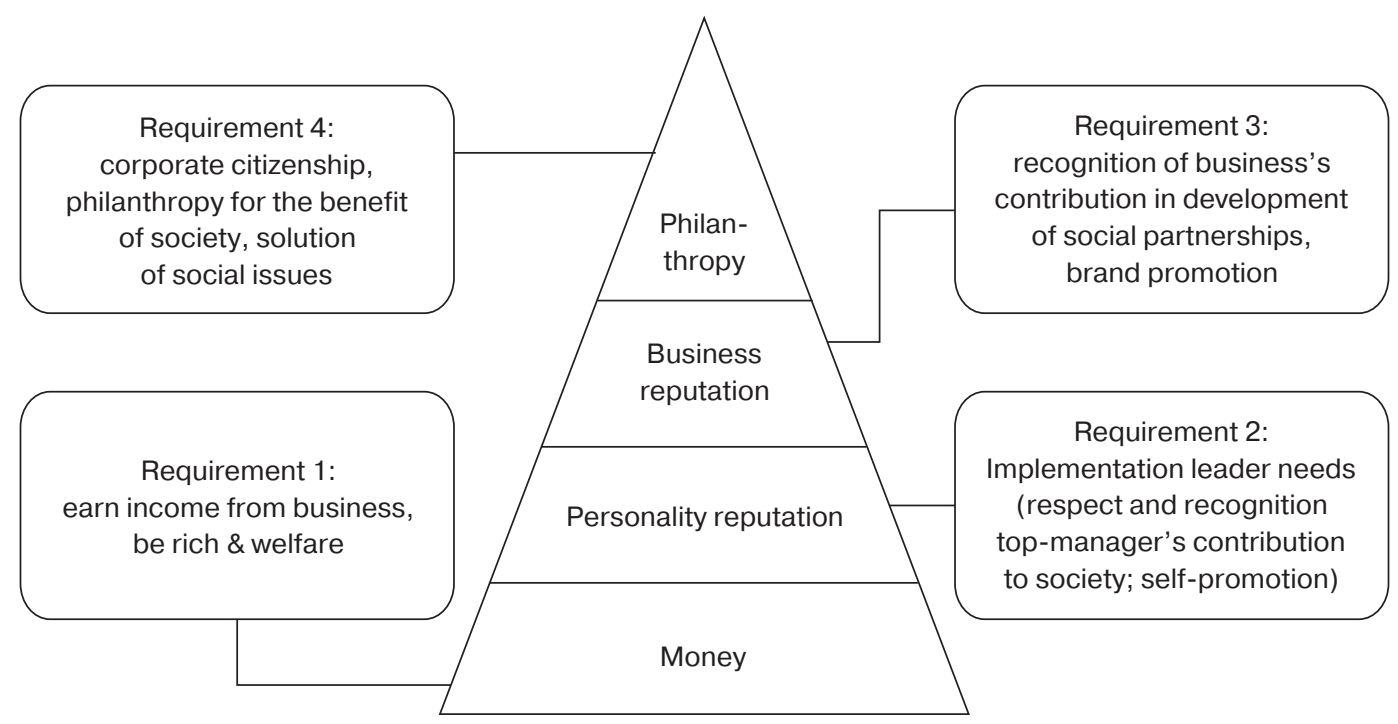

Figure. CSR Pyramid in Russia. Source: the authors' survey

As the research demonstrates, only on the top-stage corporations achieve humanism component: starting to care about employees and other stakeholders, environmental protection and green philosophy, social support for vulnerable groups, support education and science, work on alleviating social inequalities and poverty, pay attention to rural and urban areas, local communities, and to other sustainable development global goals. Thus, social investments can be considered from a manager's personal level and point of view then transform into general perspective to the municipal or governmental level. In this case, a reputation effect has risen when corporate citizen is not aimed at momentary profit and expects to receive dividends in the long run.

The respondents of the expert survey conducted by the authors share this key conclusion. Answering the question "Do you have a company in your mind that can be set as an example as socially responsible, and held a dialogue with the authorities and society to solve social problems (in the world, in the country, or in the city)": $15 \%$ of experts could not give an example of such a company. $25 \%$ called their company; the rest (most of them) mentioned external large corporations such as Facebook, Google, Gazprom, Philip Morris, Danone, Magnet, and Ronald McDonald Foundation. Representatives of nonprofit organizations and associations referred to companies - members of such NGOs.

\section{Russia: past and perfect}

As the scientists pointed out, during the Soviet period the so-called "social contract" was signed between the state and society implying that "the population does its work and respects political loyalty, and the state takes care of it" (Lapina N.Ju., 2007). Briefly speaking, in the model of state paternalism the enterprise acted as a social guarantor, fulfilled a whole range of social obligations, possessed a social public infrastructure. 
According to E. Gontmakher, "the social contract, previously signed between society and the state, went to collapse. This happened as "from above" (the state was not able to fulfill social obligations), and "from below" (there was growing dissatisfaction with the state as a "social guarantor") (Gontmakher E., 2000).

Based on the materials of economic, political, sociological content and considering some of the publications on the subject, we can distinguish at least five stages in the development of business-government relations in their Russian interpretation.

Stage 1 (1991-1995), formation of business and non-profit sector, non-systematic charity. At this stage the country begins to form entrepreneurial and non-governmental sector, relationships between business and government in the field of CSR are characterized by non-systemic charity, prevails state paternalism where the state has the primary role in dealing with the emerging business community. In 1995 it was adopted the Federal Law "On Public Associations" 1 , which was the legal basis of appearance and functioning of public institutions.

Stage 2 (1995-2000), business expansion, genesis of CSR elements. At this stage relations between government and business structures was mainly built through informal channels and personal linkages that caused corruption. The Government gradually was losing its primary role in dealing with the business, it increases the political influence of large business. Regarding the development of nonprofit sector, this period can be noted as expansion of legal field functioning of non-profit organizations (NPOs). There were the Federal laws accepted: "On charitable activities and charitable organizations" [6], "On noncommercial organizations" ${ }^{2}$. In this period there were signing trilateral agreements between the representatives of government, business organizations and trade unions. This period can be characterized as a gradual transition from a one-time assistance to individuals and organizations to finance targeted programs, formation of CSR concepts in the business environment and society as a whole.

Stage 3 (2000-2005). In the third phase there was the implementation of CSR practices in large corporations with foreign capital. This stage was characterized by the institutionalization of corporate philanthropy, allocation of corporate and private foundations and non-profit organizations to attract implementation of corporate programs, professionalization, and included active debates on social responsibility, conferences and scientific forums. In 2004, the Russian Union of Industrialists and Entrepreneurs (RSPP) had released the domestic version of the model of social responsibility - Social Charter of Russian business ${ }^{3}$. One of the tools to use global CSR practices were the publications of the first non-financial (social) reports. During the period 2000-2005, according to the report of RSPP, a number of companies that published non-financial reports, had increased from 2 to $23^{4}$. The organic part of business activity

${ }^{1}$ Federal Law No. 82-FZ from 19.05.1995 (red. from 31.01.2016) On Public Associations. URL: https://www.consultant.ru/document/cons_doc_LAW_6693

2 Federal Law No. 7-FZ from 12.01.1996 (red. from 30.03.2016) On noncommercial organizations. URL: https://www.consultant.ru/document/cons_doc_LAW_8824

${ }^{3}$ Russian Union of Industrialists and Entrepreneurs. Social Charter of Russian Business. Moscow, 2004. URL: http://www.rspp.ru/simplepage/474

${ }^{4}$ Russian Union of Industrialists and Entrepreneurs. CSR Trend Review 2009. Moscow, 2009. URL: http://www.undp.ru/index.php?iso=RU\&lid=2\&pid=2\&cmd=text\&id=272 
became sponsorship of social projects, philanthropic and other activities within the framework of socially responsible behavior.

Stage 4 (2005-2009), active implementation of CSR practices. Since 2005, topic of CSR had been becoming very popular in Russia. Large companies claim to be "socially responsible" organized and conducted numerous activities on CSR issues, in large quantities there were publications on the theory and practice of CSR in the country. In 2007, Russia first presented in international databases (www.corporateregister.com) as the country in which companies and organizations produce non-financial reporting.

Scientists believe that Russia today is on the fifth development stage of corporate citizenship practices and CSR. At this time in large international corporations, which had already achieved a lot of experience how to manage with social programs, social project plans practically unchanged despite the crisis in the economy.

As is known, in 2010 the International Standard ISO 26000:2010 "Guidance on social responsibility" " was published, the first standard in the area of socio-economic relations in general. In addition, the Russian Union of Industrialists and Entrepreneurs developed principles, recommendations and implementation guidance on ISO 26000 "Management of the Company's social responsibility" 2 . Besides, in that field the State Standard GOST R ISO 26000:2012 was approved by the Order of the Federal Agency for technical regulation and metrology in November 29, 2012, No. 1611, and entered into force in March 15, 2013 3 . The Standard is identical to the international standard "ISO 26000:2010. Guidance on social responsibility". It aimed at integrating social responsibility principles (transparency, accountability, ethical conduct) into business processes, including all areas of activity and management levels. This document addressed issues of work organization, social support of employees, relationships with all stakeholders, principles of interaction with contractors and business partners involved in socially important public tasks.

In addition to monographs and scientific articles at sufficiently high level of research, there were problems of government and business interactions carried out in Russia. The most notable practical surveys in the field of CSR are: "The practices of companies in the field of philanthropy and social investments" (based on "Corporate Donor of Russia" project) ${ }^{4}$, "Social partnership in Russia. Best practices" " "The leaders of corporate charity" 6 and others. They note the importance and relevance of researching and using the mechanism of social partnerships between business and government in the framework

1 ISO. Guidance on social responsibility draft international standard ISO/DIS 26000. Geneva, 2009. URL: http://www.iso.org/iso/catalogue_detail?csnumber $=42546$

2 Russian Union of Industrialists and Entrepreneurs. Recommendations for companies to conduct self-organization of the company in the compliance with the principles of social responsibility on the basis of the provisions of the international standard ISO 26000:2010 Guidance on Social Responsibility, 2010. URL: http://media.rspp.ru/document/1/8/4/842326d35fdf3ee2f880fa2baa22f177.pdf

${ }^{3}$ GOST Expert. GOST R ISO 26000-2012. Guidance on Social Responsibility. URL: http:// gostexpert.ru/gost/gost-26000-2012

${ }^{4}$ Forum of Donors. Leaders of corporate charity. URL: http://www.donorsforum.ru/projects/lkb.

5 Report on Social Investments in Russia-2008 / eds. Ju.E. Blagov, S.E. Litovchenko, E.A. Ivanova. Russian Managers Association. Moscow, 2008.

${ }^{6}$ Forum of Donors. Leaders of corporate charity-2015. URL: http://www.donorsforum.ru/ materials/vsyo-o-liderakh-2015; Forum of Donors. Press-center. URL: http://www.donorsforum.ru/ sections/about/presscenter/facts 
of cooperation with local communities and implementation of social policy areas into real life. As the regional interviews show, all companies in Krasnodar and Rostov-on-Don have implemented social responsible code of conduct. In some organizations, this document reflects stronger operating conditions than prescribed by the law (in oil, gas, food industries).

It's worth to note that the Russian Managers Association is a system of permanent expert-analytical platforms on key issues in the development of business community (on IT sphere, corporate governance and finance, marketing, HR-practices, CSR, foreign economic activity, legislation) for regular meetings and professional communication among the members ${ }^{1}$. Being a part of the CSR Committee, members of the Russian Managers Association create CSR standards for corporate executives, facilitate the exchange of best practices and promote consolidated position of the top-managers community in the field of CSR. Projects of the Association in business relations, public authorities and society are: the Forum "Corporate Volunteering", All-Russian Conference "Corporations - to the older generation. Inspiring corporate practices" ${ }^{3}$, the Forum "People Investor: companies investing in people" 4 and others.

Based on the information received from the experts in Krasnodar and Rostov-on-Don, we can say that Southern business supports and initiates cooperation with authorities according to unified principles of PPPs and reflects proactive attitude to such social projects (activities of the Association of European Businesses in Russia and its Southern Regional Committee). Stressing the point that often employees of the company are involved in such social and investment projects and share common values. Therefore, to the questionnaire "How do you use or practice CSR in your organization", experts responded in open detailed answers:

- CSR is an integral part of the philosophy and ideology of business, it shows the duality of business, when business itself must improve the life around, provide health through food;

- CSR is used through the company's social policy, social package, benefits (we pay taxes, comply with legislation, train and develop employees);

- CSR as a code of procedures and rules which are often much more stringent than the legislation of the Russian Federation;

- CSR as a charity with active involvement of employees;

- CSR is built into the business model of sustainable development aimed at introduction of new knowledge and new technologies for the benefits of future generations where social and educational projects are aimed at increasing the importance of quality education in modern society, as well as introduction and development of economic knowledge; projects cover all participants of educational and scientific processes (teachers, students, schoolchildren and young professionals);

- CSR may also include organization of pre-graduation practices in either workplace or organization as well as scholarship programs, workshops and grants from the endowment funds in some organizations.

${ }^{1}$ Russian Managers Association. URL: http://www.amr.ru/committees/kso

2 Forum "Corporate Volunteering". URL: http://www.amr.ru/projects/corpvol

${ }^{3}$ Conference Companies to the older generation. URL: http://www.b-soc.ru/center/our-meetings/ meeting/80

${ }^{4}$ Forum "People Investor”. URL: http://amr.ru/projects/pinvestor 


\section{From traditional philanthropy to social investments}

The Russian Managers Association presented a very close to theoretic scientists approach to the evolution of business participation in social development of society (Table). The Association did not specify the periods of pre-emptive use of a certain type of CSR, and allocated possible levels of business participation in social development ${ }^{1}$.

Levels of business participation in social development

\begin{tabular}{|l|l|l|l|}
\hline & Traditional philanthropy & \multicolumn{1}{|c|}{ Strategic philanthropy } & \multicolumn{1}{|c|}{ Social investments } \\
\hline Motivation & $\begin{array}{l}\text { Selflessness and desire } \\
\text { to help }\end{array}$ & $\begin{array}{l}\text { The strategic interests of the } \\
\text { company that are not highly related } \\
\text { to the objectives of its development }\end{array}$ & $\begin{array}{l}\text { Long-term interest of the } \\
\text { company, integrating the } \\
\text { company's interests and the } \\
\text { needs of local communities }\end{array}$ \\
\hline $\begin{array}{l}\text { Criteria for } \\
\text { selection of } \\
\text { beneficiaries } \\
\text { of funds }\end{array}$ & $\begin{array}{l}\text { Wishes } \\
\text { of top management }\end{array}$ & $\begin{array}{l}\text { Consider beneficiary interests, } \\
\text { social efficiency }\end{array}$ & $\begin{array}{l}\text { Social efficiency, the need of } \\
\text { the local community and the } \\
\text { business benefits (in the future) }\end{array}$ \\
\hline $\begin{array}{l}\text { Communication } \\
\text { with the main } \\
\text { activity }\end{array}$ & Not connected & Connected indirectly & $\begin{array}{l}\text { Internal corporate programs- } \\
\text { directly, and external social } \\
\text { programs - indirectly in hope } \\
\text { of deferred effect }\end{array}$ \\
\hline $\begin{array}{l}\text { Finance } \\
\text { Mechanisms }\end{array}$ & $\begin{array}{l}\text { Charitable donations } \\
\text { sponsorship }\end{array}$ & $\begin{array}{l}\text { Charitable donations, sponsorship, } \\
\text { grant programs, not related to } \\
\text { business interests of the company }\end{array}$ & $\begin{array}{l}\text { Inter-sectoral } \\
\text { social partnership }\end{array}$ \\
\hline
\end{tabular}

The positive view is seen by the fact that despite the crisis the Russian companies often increase the budgets of charitable programs. For example, according to the results of annual contest "The leaders of corporate charity-2015", the winners were the largest corporations such as "Gazprom Neft", "Severstal", "Metalloinvest" (Malykhin M., 2015). Also we would like to note that the competition "Leaders of corporate charity" is a joint project of the non-commercial partnership "Donors Forum", the business newspaper "Vedomosti" and the international network of audit and consulting firm "PwC". The purpose of the project is to identify the best companies and charitable programs of information dissemination in order to attract attention of the public, business, government and media to corporate philanthropy in Russia. The project partners are the Ministry of Economic Development of the Russian Federation and the Russian Union of Industrialists and Entrepreneurs, which announced nominations and choose the best projects.

It is necessary to summarize and highlight the main conclusions of the "Leaders of corporate charity" award, which can be noted in the development of CSR practices in cooperation with the state, society and business:

- Children are the most important beneficiaries;

1 Perekrestov D.G., Povarich I.P., Shabashev V.A. Korporativnaja social'naja otvetstvennost': voprosy teorii i praktiki. [Corporate Social Responsibility: Issues of Theory and Practice]. M., 2011. URL: http://www.monographies.ru/ru/book/section?id=4586; Report on Social Investments in Russia-2008 / eds. Ju.E. Blagov, S.E. Litovchenko, E.A. Ivanova. Russian Managers Association. Moscow, 2008. 
- Businessmen in their minds have a clear understanding of the difference between CSR and charity, it is presented the separation of these activities in projects and programs;

- The work to identify the effectiveness of such programs is going on;

- There is a willingness to disclose information about ongoing projects, their cost and represent them by an independent appraiser to the media and other stakeholders;

- In any business rounds, finally, there is a desire to be socially responsible, to have social ambitions as a goal and use measurable business activities;

- Despite the economic crisis in the country and in the world companies' participation in general has not changed according to budgets on social programs, some has even increased them.

- Large corporations have begun to play a driver role in regional sustainable development of local territories, rural areas, bringing the business-know-how-technologies and ideas, providing intelligent component and career development of staff, expert capabilities to address regional social development, being a moderator and a driving force in the interaction of state and society;

- Social partnership includes the participating role of business with a system approach to social activities, when the budget for CSR is planned in advance. However, the companies are still considering alternatives to social investment: how to achieve maximum results with minimum costs;

- During the crisis periods, the business actively used alternative of charity, such as corporate volunteering, collecting private donations, pro-bono services, social-oriented marketing and social entrepreneurship. Today in Russia there is also optimization in corporations of social activity costs, when management refuses, for example, outsourcing services and closely involves employees as volunteers in charitable and sponsorship projects. Volunteering serves as the excellent tool for employee engagement in company's social activities, a kind of team-building, helps to improve professional competencies, increase loyalty and efficiency of horizontal communication.

According to experts from the South of Russia, corporate volunteering is often an important tool for meaningful social changes and for building corporate communications. Answering the question "What volunteer activities are the most often held in your company?", the respondents' answers covered a wide range of activities: lecturing for students on financial literacy and basics of entrepreneurships in regional universities; holding relay races of good deals in the city or district; going out to streets on Saturday volunteering (subbotnik); gifts campaigns for the New Year for children from disadvantaged families, disabled, gifts to veterans to the Victory's Day; participation in charitable sports events (races, marathons); in some companies it is possible to leave to another country as a volunteer to help those in need; actions to collect donor blood.

\section{From economics to politics}

In recent years, the political leaders of our country had been increasingly talking about the importance of corporate social responsibility, calling on corporations to cooperate with public authorities in their pathways to solving social problems and faced challenges. Such activation demonstrates an increased interest in the issue at the highest political level, but at the same time, it creates a risk unacceptably high degree of market economy 
regulation. Effective relations in "state-business-society" triada on issues of social responsibility is becoming one of the state policy directions.

The relevance of the CSR demonstrated by the fact that in 2010 the discipline "Corporate Social Responsibility" was introduced in the Federal educational standard of higher education in the field of study "Management". This provision suggests that the Ministry of Education pays a great attention to modern Russian management knowledge and skills not only in strategic planning, personnel management, finance, risk, investments, but in social responsibility as well.

Besides, development of social partnerships and investments in human capital in Russia is defined as one of the transition priorities of the Russian economy to innovative socially oriented type. This postulate is reflected in the long-term development of the Russian Federation up to 2020. It should be noted that the business is ready to plan the social budget not only for the programs for their employees, but also for general improvement of the social environment and the quality of life of local communities in the cities and regions where it located. Thus, rapid institutional changes and system additions of CSR concept in Russia gradually move to a more mature level - the level of corporate citizenship where the company treats as a real "citizen" of society.

\section{Conclusion}

Based on concepts of CSR and corporate citizenship we can identify the main factors pushing Russian business to expand using corporate citizenship practices:

- Development and implementation of CSR norms and standards, adoption of charters, memorandums and corporate codes of conduct necessary for a positive image and reputation of a "responsible citizen";

- Ability to achieve certain beneficial advantage with increased competition in domestic and world markets, as in some countries, for example, absence of certification ISO 26000 standard eliminates the possibility of obtaining a state order;

- Increasing pressure on stakeholders (government, shareholders, employees, local communities) associated with great expectations from the business;

- Growing activity of public authorities aimed at attracting businesses to solve social and economic problems of society including new forms of such relations (PPPs concessions);

- Acknowledged role of professional non-beneficial organizations and nongovernmental organizations in the effective implementation of social projects and business programs.

Elements of corporate citizenship such as CSR, social partnership, public-private partnerships, social investments reflect the transition from a company's charity to focused investments at national and regional levels aimed at addressing the most urgent issues for the country in the field of employment, poverty alleviation, education, safety, health, green economy issues and global warming mitigation (Votchenko E.S., 2017).

We can realize that today on the regional scale business as a whole is able to be a social investor, supporting the sphere of science, education, culture, health - those areas that are considered to be social. Social investments in this process could be a driver and boost public-private partnerships to a new development era. 
In general, the main dimensions for the development of the institutional (organized) CSR system in Russia and social investments can be described as follows:

- charity in the country and regions acquires a systemic trends;

- new people and organizations are involved in philanthropic activities;

- business actively uses alternative options for charity, such as corporate volunteering, collecting private donations, providing free services, socially-oriented marketing, social entrepreneurship;

- education is one and promising area of social investments;

- funds of the target capital, endowment funds become one of the options for implementing projects in multy-sectoral relations in educational sphere of social regional policy;

- children and students act as one of the most important beneficiaries of charity;

- a clear understanding of the difference between CSR and charity has been formed in corporate business programs;

- business has a desire to be socially responsible;

- corporations began to play the role of a driver for regional sustainable development, urban and rural areas, introducing business technologies, providing intellectual component and career growth of personnel, expert opportunities to address issues of social development in the region, as a moderator and driving force in the interaction of the state and society.

We suggest that formation of social investments' concepts in its narrow sense and its broad definition as corporate citizenship in Russia goes through a lag, but in line with global trends and touches large corporations so far. Integration corporate citizenship principles in company's activities could allow them to gain a number of competitive advantages, to create a positive image and become responsible "citizens" of their society. This is what the Nobel Prize awarder Milton Friedman was talking about in his The New York Times article (Friedman M., 1970).

\section{REFERENCES}

Blagov Ju.E. Koncepcija korporativnoj social'noj otvetstvennosti i strategicheskoe upravlenie // Russian Journal of Management. 2004. T. 2. № 3. P. 17-34. (In Russ).

Blagov Ju.E. Korporativnaja social'naja otvetstvennost': jevoljucija koncepcii. SPb., 2011. (In Russ).

Carroll A.B. A Three-Dimensional Conceptual Model of Corporate Performance // Academy of Management Review. 1979. No. 4(4). P. 497-505.

Carroll A.B. The pyramid of corporate social responsibility: Toward the moral management of organizational stakeholders // Business Horizons. 1991. Vol. 34. Is. 4. July-August. P. 39-48.

Conference Companies to the older generation. URL: http://www.b-soc.ru/center/our-meetings/ meeting/80

Federal Law No. 135-FZ from 11.08.1995 (red. from 05.05.2014) On charitable activities and charitable organizations. URL: http://www.consultant.ru/document/cons_doc_LAW_7495

Federal Law No. 7-FZ from 12.01.1996 (red. from 30.03.2016) On noncommercial organizations. URL: https://www.consultant.ru/document/cons_doc_LAW_8824

Federal Law No. 82-FZ from 19.05.1995 (red. from 31.01.2016) On Public Associations. URL: https:// www.consultant.ru/document/cons_doc_LAW_6693

Forum “Corporate Volunteering”. URL: http://www.amr.ru/projects/corpvol 
Forum “People Investor”. URL: http://amr.ru/projects/pinvestor

Forum of Donors. Leaders of corporate charity. URL: http://www.donorsforum.ru/projects/lkb

Forum of Donors. Leaders of corporate charity-2015. URL: http://www.donorsforum.ru/materials/ vsyo-o-liderakh-2015

Forum of Donors. Press-center. URL: http://www.donorsforum.ru/sections/about/presscenter/facts

Friedman M. The Social Responsibility of Business is to Increase its Profits // The New York Times Magazine. 1970. September 13.

Gontmakher E. Social'naja politika: uroki 90-h. M., 2000. (In Russ).

GOST Expert. GOST R ISO 26000-2012. Guidance on Social Responsibility. URL: http://gostexpert. $\mathrm{ru} /$ gost/gost-26000-2012

ISO. Guidance on social responsibility draft international standard ISO/DIS 26000. Geneva, 2009. URL: http://www.iso.org/iso/catalogue_detail?csnumber $=42546$

Korolev E.A. Vzaimodejstvie biznesa i vlasti na primere politicheskih institutov Evropejskogo Sojuza: avtoref. diss. ... cand. polit. nauk. M., 2009. (In Russ).

Korporativnaja social'naja otvetstvennost' i konkurentosposobnost' / ed. A. Dynkin. M., 2004. (In Russ).

Lapina N.Ju. Uroki social'nyh reform v Rossii: regional'nyj aspekt. Analiticheskij obzor. M., 2007. (In Russ).

Lapina N.Ju., Chirikova A.E. Regiony - lidery: jekonomicheskie aktory, struktura vlasti, politicheskoe i informacionnoe prostranstvo. M., 2002. (In Russ).

Malykhin M. Blagotvoritel'nost' vne krizisa [Charity is out of the crisis] // Vedomosti. No. 3968. 26.11.2015. URL: http://www.vedomosti.ru/management/articles/2015/11/26/618377-voprekikrizisu-kompanii-naraschivayut-byudzheti-blagotvoritelnih-programm

Pappe Ya.Sh. Rossijskij krupnyj biznes: Sobytija i tendencii. M., 2004. (In Russ).

Pavroz A.V. Biznes i gosudarstvo v Rossii: Fundamental'nye problemy vzaimodejstvija i strategii. M., 2010. (In Russ).

Peregudov S.P. Biznes i vlast' v Rossii: k novoj modeli otnoshenij. Vlastnye jelity sovremennoj Rossii. Business press. URL: http://www.businesspress.ru/newspaper/article_mId_40_aId_297056.html

Peregudov S.P. Korporacii, obshhestvo, gosudarstvo: jevoljucija otnoshenij. M., 2003. (In Russ).

Peregudov S.P. Krupnaja korporacija kak subjekt publichnoj politiki. M., 2006. (In Russ).

Peregudov S.P., Semenenko I.S. Korporativnoe grazhdanstvo: koncepcii, mirovaja praktika i rossijskie realii. M., 2008. (In Russ).

Perekrestov D.G., Povarich I.P., Shabashev V.A. Korporativnaja social'naja otvetstvennost': voprosy teorii i praktiki. M., 2011. URL: http://www.monographies.ru/ru/book/section?id=4586

Report on Social Investments in Russia-2008 / eds. Ju.E. Blagov, S.E. Litovchenko, E.A. Ivanova. Russian Managers Association. Moscow, 2008.

Russian Managers Association. URL: http://www.amr.ru/committees/kso

Russian Union of Industrialists and Entrepreneurs. CSR Trend Review 2009. Moscow, 2009. URL: http://www.undp.ru/index.php?iso=RU\&lid=2\&pid=2\&cmd=text\&id=272

Russian Union of Industrialists and Entrepreneurs. Recommendations for companies to conduct selforganization of the company in the compliance with the principles of social responsibility on the basis of the provisions of the international standard ISO 26000:2010 Guidance on Social Responsibility, 2010. URL: http://media.rspp.ru/document/1/8/4/842326d35fdf3ee2f880fa2baa 22f177.pdf 
Russian Union of Industrialists and Entrepreneurs. Social Charter of Russian Business. Moscow, 2004. URL: http://www.rspp.ru/simplepage/474

Russian Union of Industrialists and Entrepreneurs. Social Responsibility. URL: http://rspp.ru/ simplepage $/ 472$

Tehnologii obshhestvennogo uchastija i mezhsektornogo social'nogo partnerstva [Technologies of public participation and intersectoral social partnership] / ed. M.B. Gorniy. SPb., 2013. URL: https://www.hse.ru/pubs/share/direct/document/115119611

Turkin S. Zachem biznesu social'naja otvetstvennost' // Upravlenie kompaniej. 2004. No. 7. URL: http://www.cfin.ru/press/zhuk/2004-7/16.shtml

Turovskiy R. Gubernatory i oligarhi: istorija otnoshenij // Politija. 2001. № 5. (In Russ).

Votchenko E.S. Kontinental'nye modeli korporativnoj social'noj otvetstvennosti: obshhee i osobennoe // RUDN Journal of Economics. 2017. T. 25. № 3. P. 417-426. DOI: 10.22363/2313-2329-201725-3-417-426. (In Russ).

Votchenko E.S. Russian "Pyramid" as a tool to evaluate social investments // International Research Journal. 2016. No. 10 (52), part 1. P. 123-125. DOI: 10.18454/IRJ.2016.52.060.

Votchenko E.S., Bogdashev I.V. Social'noe investirovanie v sovremennyh gosudarstvah. Krasnodar, 2018. (In Russ).

Yakimets V.N. Mezhsektornoe social'noe partnerstvo v Rossii: opredelenie, mehanizmy, luchshie praktiki. URL: http://www.kdobru.ru/materials.pdf

Yakimets V.N. Mezhsektornoe social'noe partnerstvo: vozmozhnosti i ogranichenija. M., 2001. (In Russ).

Yakimets V.N. Social'nye investicii rossijskogo biznesa: mehanizmy, primery, problemy, perspektivy. M., 2005. (In Russ).

Zudin A. Gosudarstvo i biznes v Rossii: jevoljucija modeli vzaimootnoshenij // Neprikosnovennyj zapas. 2006. № 6 (50). (In Russ).

Zudin A. Neokorporativizm v Rossii? (Gosudarstvo i biznes pri V. Putine) // Pro et contra. 2001. № 4. (In Russ).

(C) Votchenko E.S., Bogdashev I.V., 2018

\section{Article history:}

Received: 13 February 2018

Revised: 22 February 2018

Accepted: 2 March 2018

\section{For citation:}

Votchenko E.S., Bogdashev I.V. (2017) Social investments at a glance: reviewing Russian perspectives. RUDN Journal of Economics, 26 (1), 47-60. DOI: 10.22363/2313-2329-2018-26$1-47-60$

\section{Bio Note:}

Ms. Votchenko Elena S., PhD in Politics, Marketing and Trading Business Department, Kuban State University. Lecturer in Double-Degree Program "Economics and Management". Practitioner. Contact information: e-mail: evotchenko@gmail.com

Mr. Bogdashev Ilya V., PhD in Economics, associate professor, Theoretical Economics Department, Kuban State University. Lecturer in Double-Degree Program "Economics and Management". Contact information: e-mail: ilbogdashev@gmail.com 


\title{
СОЦИАЛЬНОЕ ИНВЕСТИРОВАНИЕ: ПЕРЕСМАТРИВАЯ РОССИЙСКИЕ РЕАЛИИ
}

\author{
Е.С. Вотченко, И.В. Богдашев \\ Кубанский государственный университет| \\ ул. Ставропольская, 149, Краснодар, Россия, 350040
}

\begin{abstract}
Цель настоящего исследования заключается в анализе современных тенденций и этапов развития социального инвестирования и корпоративной социальной ответственности (КСО) в России. Статья затрагивает актуальную тему взаимодействия триады «государство-бизнесобщество» в российском публичном дискурсе. Рассматривая системные подходы и методологию развития отношений между государством и частным сектором, авторы пытаются обобщить накопленный опыт в сфере КСО и социального инвестирования. Стоит отметить, что российскими учеными на достаточно высоком уровне проработан понятийный аппарат предмета настоящего исследования, определены и систематизированы общественные ожидания, обобщен реальный опыт социально ответственных российских и зарубежных корпораций. Статья выявляет интересный феномен: в современном научном сообществе формируется новая институциональная парадигма, когда КСО в узком понимании данной дефиниции выходит за рамки простой благотворительности и филантропии и сегодня представлена в широком смысле - как концепция корпоративного гражданства, включающая и политическое измерение. Кроме того, в статье представлены показательные результаты авторского прикладного исследования «Анализ опыта социального партнерства бизнеса и органов государственной власти, социального инвестирования и КСО», проведенного в Краснодаре и Ростовена-Дону в 2016-2017 гг.
\end{abstract}

Ключевые слова: корпоративная социальная ответственность, социальные инвестиции, государственно-частное партнерство, взаимодействие бизнеса и власти, корпоративное гражданство

\section{История статьи:}

Дата поступления в редакцию: 13 февраля 2018

Дата принятия к печати: 2 марта 2018

\section{Для цитирования:}

Вотченко Е.С., Богдашев И.В. Социальное инвестирование: пересматривая российские реалии // Вестник Российского университета дружбы народов. Серия: Экономика. 2018. T. 26. № 1. C. 47-60. DOI: 10.22363/2313-2329-2018-26-1-47-60

\section{Сведения об авторах:}

Вотченко Елена Сергеевна, кандидат политических наук, преподаватель кафедры маркетинга и торгового дела экономического факультета Кубанского государственного университета. Контактная информация: e-mail: evotchenko@gmail.com

Богдашев Илья Владимирович, кандидат экономических наук, доцент, доцент кафедры теоретической экономики экономического факультета Кубанского государственного университета. Контактная информация: e-mail: ilbogdashev@gmail.com 